\title{
Response of Erosion and Deposition of Channel Bed, Banks and Floodplains to Water and Sediment Changes in the Lower Yellow River, China
}

\author{
Xiaofei Liu ${ }^{1,2} \mathbb{D}$, Changxing Shi ${ }^{1, * \mathbb{D}}$, Yuanyuan Zhou ${ }^{1}$, Zhenkui Gu ${ }^{1,2}$ and Huijuan Li $^{1,2}$ \\ 1 Key Laboratory of Water Cycle and Related Land Surface Processes, Institute of Geographic Sciences \\ and Natural Resources Research, Chinese Academy of Sciences, 11A Datun Road, Chaoyang District, \\ Beijing 100101, China; liu19890616@126.com (X.L.); zhouyy.09b@igsnrr.ac.cn (Y.Z.); \\ bygzk853@126.com (Z.G.); lihj.17b@igsnrr.ac.cn (H.L.) \\ 2 University of Chinese Academy of Sciences, Beijing 100049, China \\ * Correspondence: shicx@igsnrr.ac.cn
}

Received: 15 January 2019; Accepted: 18 February 2019; Published: 20 February 2019

\begin{abstract}
River channel change can be very sensitive to environmental change and human activities and it has been one of the main research topics in fluvial geomorphology. In this study, repeated channel geometric measurements were used to investigate the channel adjustment to water and sediment changes of the lower Yellow River in China in the past few decades. With a high sediment concentration and large variations of water discharge, the lower Yellow River has a much active channel in its form and location, which has hindered previous research efforts to study long-term differentiated erosion/deposition of different geomorphic units in the channel. In this study, we divided each of four typical channel across-sections at hydrological stations in the lower Yellow River into different units according to the geomorphological features, and give a detailed investigation of erosion/deposition processes of these geomorphic units and the interactions between them besides the influence of incoming water and sediment conditions. The results show that with a significant decreasing trend of both the annual runoff and sediment load of the river and abrupt changes in 1985-1996, the overall siltation trend in the river channel before 1990 had been replaced by a slight erosion trend after 2006. In the earlier period, the siltation in the upstream wandering and transitional reaches mainly occurred on floodplains and that in the downstream straight reaches principally on main channel bed. In the later period, erosion occurred mainly on high and low bank slopes in the wandering reaches and on main channel bed in the transitional reaches. The erosion became weak in the wandering reaches after 2010, continued in the transitional reaches, and was still relatively minor in the straight reaches, reflecting the downstream hysteresis channel response to changes in water and sediment discharges down dams. Our results suggest that the seasonal erosion/deposition of a geomorphic unit of the river channel can be attributed to the changes in water and sediment discharges as well as to the interaction between geomorphic units. Siltation on the main channel bed could be attributed to erosion on the bank slopes in both the sections in the wandering and transitional reaches, and erosion of the main channel bed in flood seasons was negatively related with the mean water discharge at the two sections in the straight reaches. This result implies that fixing the bank slopes in the wandering and transitional reaches and raising the water discharge in the straight reach in flood seasons are favorable options for controlling the development of the two-level perching channel of the lower Yellow River.
\end{abstract}

Keywords: lower Yellow River; geomorphic unit; channel erosion and siltation; river channel pattern 


\section{Introduction}

Climate change and human activities have greatly changed the water and sediment conditions of rivers [1-8]. From a global perspective, the impact of human activities, especially the construction of reservoirs and soil and water conservancy projects on rivers is greater than that of climate change [2,9-13]. It was found that the operation of reservoirs changed the intra-annual distribution of water and sediment, reduced flood peak flows, and hence had a certain impact on the erosion and silting in the downstream river channels and their geometric adjustment [12,14-17]. Also, soil and water conservation projects in the Yellow River basin have affected the scouring and silting processes in the river's mainstream channel by changing the water-sediment regime [18-23].

Scouring and siltation of river channels is not only affected by incoming water and sediment, but also related to the boundary conditions of the river channels. By investigating more than 200 rivers in the United States, Brice [24] found that the lateral swing rates of different channel patterns are different, and the mean lateral swing rate of the river channels with a constant width is the smallest. In the straight channels, when the width difference between the bend and the straight transition section is large, the section is prone to lateral swing. It was also found that the transverse changes of the channel were influenced by the original channel morphology [25], and the sedimentation process of floodplains was affected by various factors such as the topographic changes of the floodplain itself [26].

Since channel scouring and siltation is affected by various factors [27-29], the processes of scouring-siltation are usually very complex and demand further investigation of more examples for understanding the response of channel adjustment to changing environments. The heavy channel siltation in the sediment-laden lower Yellow River induced frequent flood disasters in north China in history and eliminated the effect of flood control practices in the past decades [30], hence the processes and causes of channel scouring and siltation of the river have caught the attention of many scholars [31,32].

One of the main data used in the investigation of channel scouring and siltation is measurements of channel geometry, and erosion and sediment deposition in the main channel and floodplains can be extracted from the repeated channel cross-section surveys. Yet, the Yellow River has a very active channel, which has swung laterally frequently and drastically. For calculating erosion and sediment deposition on floodplains and in main channel from a large amount of channel geometry measurements, previous studies usually fixed the locations of the left and right boundaries of the main channel in a cross-section, so part of floodplains are included between the two boundaries besides the main channel and the calculated results cannot strictly reflect the actual scouring and silting of the main channel and floodplains. Recently, Shen [33] used the method of "a moving main channel with a fixed width" for dividing the main channel and floodplains. Although this method is more effective than that used in previous studies, it is still not able to reflect the evolution process of different landform units in detail. Based on the data of some typical cross-sections of the lower Yellow River, this paper divided each of the sections according to their geomorphic characteristics and studied the scouring and silting processes of channel bed, banks and floodplains in the past decades.

\section{Study Area}

The lower Yellow River flows in a channel raised above the plains outside the artificial levees with a length of about $786 \mathrm{~km}$ on the North China Plain starting from Taohuayu, and enters the Bohai Sea about $70 \mathrm{~km}$ downstream of Qianzuo. The lower Yellow River has a compound channel with a main channel and floodplains between artificial levees, and the floodplains in some reaches can be subdivided into high and low ones. The main channel can contain the small and medium flows, and the floodplains are often inundated by high flows [19]. In the reach from Taohuayu to Gaocun, the river channel has a wandering pattern. Downstream of Gaocun, the river is more artificially controlled. The channel in the reach from Gaocun to Aishan has a transitional pattern, and in the reach from Aishan to Lijin it has a straight pattern with some sinuous segments (Figure 1). 

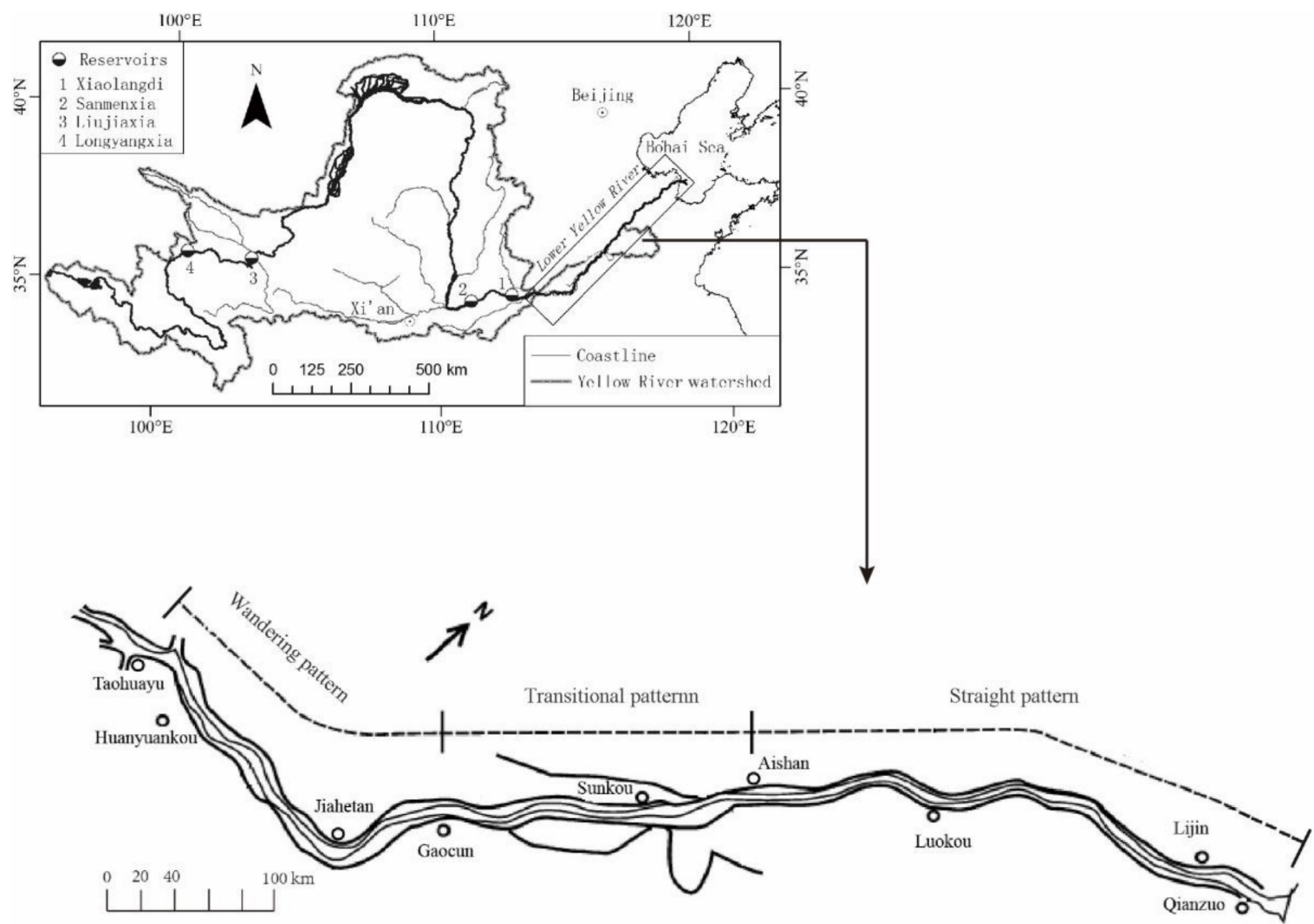

Figure 1. The lower Yellow River.

The processes of channel siltation in the lower Yellow River have been obviously altered by human activities, especially the large dams built on the mainstream of the river in its upper and middle reaches. Among the large dams, Sanmenxia Reservoir was built in the later years of the 1950s and was put into use since September 1960. During the first four years, the dam detained both water and sediment, and serious siltation occurred behind the dam. With less sediment released from the reservoir, the lower Yellow River channel was scoured in the years from 1960 to 1964 [34]. In 1965, the releasing capacity of the reservoir was promoted, leading to the reoccurrence of heavy siltation in the lower Yellow River [34]. With the Sanmenxia Reservoir being used to store clear water and release muddy floods after 1974, the impounding of Liujiaxia Reservoir after 1968 and Longyangxia Reservoir after 1986 in the upper Yellow River, and soil erosion control practices in the river basin as well as climate change, the runoff and sediment load of the lower Yellow River were further altered, and siltation in the main channel was enhanced, resulting in the formation of "two-level perching channel" [19]. After 1999, sediment detainment and flow regulation by the newly built Xiaolangdi Reservoir have alleviated the aggradation of the lower Yellow River [35]. However, after the Xiaolangdi Reservoir enters the stage of detaining floods and releasing sediment in the future, the problem of further uplifting of the "two-level perching channel" cannot be underestimated [36].

\section{Materials and Methods}

There are seven hydrological stations in the lower Yellow River, including Huayuankou, Jiahetan, Gaocun, Sunkou, Aishan, Luokou, and Lijin. The channel cross-section at each hydrological station was measured several times a year and the measurements were published on the hydrological yearbook. This paper selects Jiahetan hydrological station in the reach with the wandering pattern, Gaocun hydrological station in the reach with the transitional pattern, Luokou and Lijin hydrological stations in the reaches with the straight pattern to carry out the research. Two measurements of channel cross-sections made before and after the flood season of every year from 1965 to 2014 were used, 
but the data in the years between 1990 and 2005 are not available because the hydrological yearbooks in these years are not issued.

In order to truly reflect the scouring and siltation processes of each distinctive landform unit of a river channel, the channel cross-section is divided into the river bed, floodplains and river banks according to the geomorphic features in this paper. The floodplains are divided into high and low ones, and the river banks are divided into high river bank and low river bank. In some reaches of the lower Yellow River, local people built production embankments to protect their farmlands from flooding on the high floodplains. To clarify whether the production embankments impact siltation on the high floodplains, the high floodplains are divided into two parts by the production embankments. In this way, from the left to the right levees, the channel is divided into 11 geomorphic units, including the left high floodplain from the left levee to the left production embankment, the left high floodplain from the production embankment to the top of the left high bank, the left high bank slope, the left low floodplain from the foot of the left high bank slope to the top of the left low bank, the left low bank slope, the main channel bed, and the five corresponding units on the right side of the channel bed (Figure 2), but not all geomorphic units exist in every section. By calculating the amount of erosion and siltation of every geomorphic unit, it is possible to draw a more objective and detailed pattern of the erosion and deposition in the river channel.

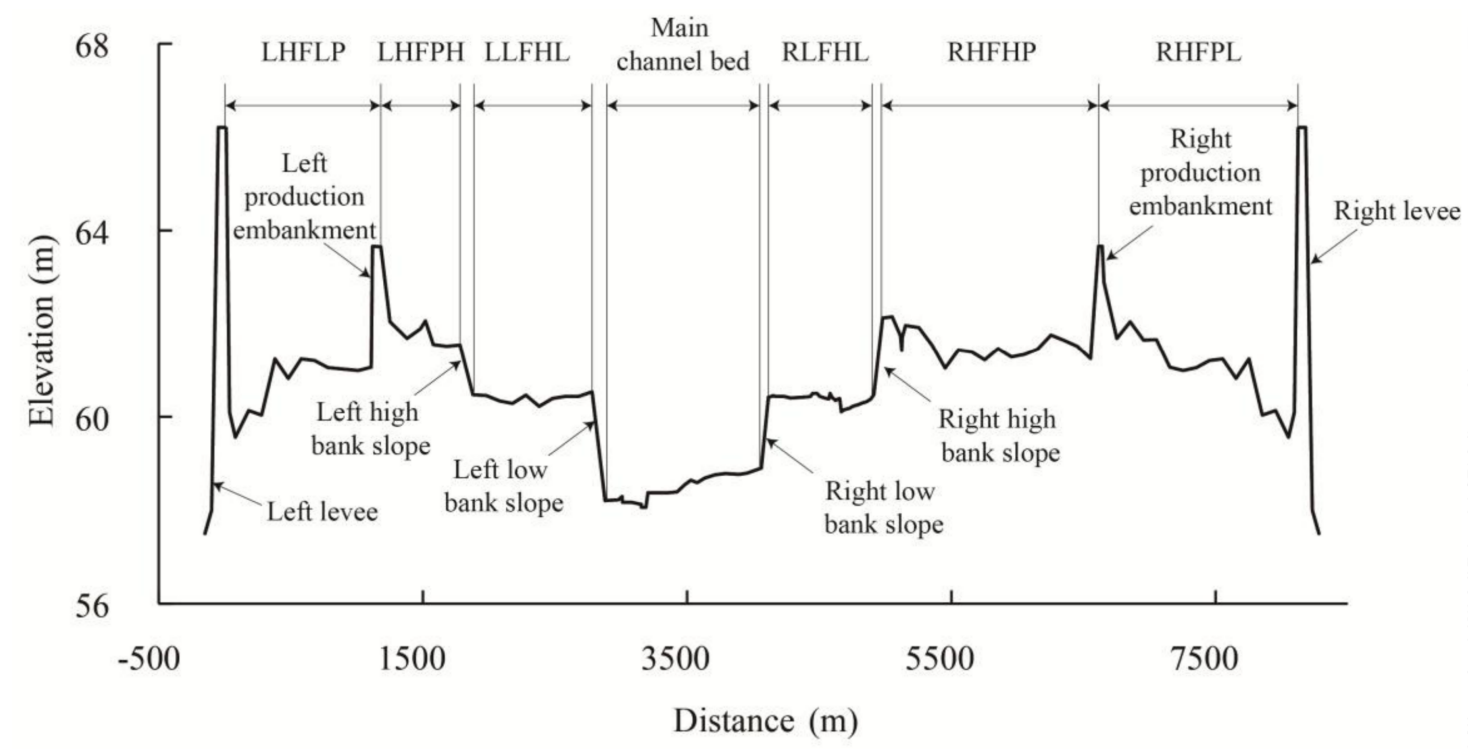

LHFLP Left high floodplain from the left levee to left production embankment

LHFPH Left high floodplain from the production embankment to the top of the left high bank

LLFHL Left low floodplain from the foot of the left high bank slope to the top of the left low bank

RLFHL Right low floodplain from the foot of the left high bank slope to the top of the left low bank

RHFHP Right high floodplain from the top of the right high bank to production embankment

RHFPL Right high floodplain from the right production embankment to right levee

Figure 2. A channel cross-section of the lower Yellow River, showing a complete division of geomorphic units.

In this paper, the amounts of erosion and deposition of a geomorphic unit during the time interval between two adjacent measurements are calculated by the area enclosed by the survey points on the unit of the two measurements. Taking the left low floodplain as an example, the survey points from the left and right ends of the floodplain are represented by $\left(x_{i, j}, h_{i, j}\right), j=1, \ldots, m$ for the $i$ th measurement, and $\left(x_{i+1, j}, h_{i+1, j}\right), j=1, \ldots, n$ for the next measurement, where $x$ is the distance of a survey point from the left end of the measured cross section, and $h$ is the elevation of the point above sea level. Then, we used the two sequences of measurements to construct a new sequence by appending the points of the $i$ th measurement in a reversed order to the end of the $i+1$ th measurement and adding the first point of the $i+1$ th measurement at the end, i.e., $\left(x_{i+1,1}, h_{i+1,1}\right),\left(x_{i+1,2}, h_{i+1,2}\right), \ldots,\left(x_{i+1, n}, h_{i+1, n}\right),\left(x_{i, m}, h_{i, m}\right)$, 
$\left(x_{i, m-1}, h_{i, m-1}\right), \ldots,\left(x_{i, 1}, h_{i, 1}\right),\left(x_{i+1,1}, h_{i+1,1}\right)$. Using $\left(X_{i}, H_{i}\right), i=1, \ldots, m+n+1$ to represent the $i$ th point in the new sequence, the amount of erosion or deposition (in $\mathrm{m}^{2}$ ) on the left low floodplain during the time interval between the two measurements is calculated as follows:

$$
\Delta S=\sum_{i=1}^{m+n} \frac{\left(H_{i}+H_{i+1}\right)\left(X_{i+1}-X_{i}\right)}{2}
$$

where a positive value of $\Delta S$ means the occurrence of siltation, and a negative value means the occurrence of erosion.

This study also used the data of daily mean water discharge and sediment load at Jiahetan, Gaocun, Luokou and Lijin hydrological stations recorded in the hydrological yearbooks issued by the Yellow River Conservancy Commission.

\section{Results}

\subsection{Changes of Annual Runoff and Sediment Load of the River}

Figure 3 shows the changes of the annual mean water and sediment discharges at Huayuankou, Gaocun, Luokou and Lijin hydrological stations. It is clear that the inter-annual changes of both the water and sediment discharges at all hydrological stations are significant with a noticeable decreasing trend. The Mann-Kendall test [37] was used to analyze the significance of the general trends of changes in annual mean water and sediment discharges at the four hydrological stations. The statistic $U$ values of the Mann-Kendall test for annual mean water and sediment discharges at Huayuankou, Gaocun, Luokou and Lijin hydrological stations were found to be -4.27 and $-7.08,-4.19$ and $-7.23,-4.16$ and $-6.61,-4.51$, and -6.12 respectively. Their absolute values were all greater than 1.96 (at the significance level of 0.05 ), so both of the annual mean water and sediment discharges at every station have a significant decreasing trend. Furthermore, using the Pettitt test [38], a widely used method for detecting change points in a sequence of observations, we found that an abrupt decline of the annual mean water and sediment discharges at Huayuankou, Gaocun, Luokou and Lijin hydrological stations occurred in 1990 and 1996, 1986 and 1995, 1986 and 1985, 1986 and 1996, respectively, at a significance level less than 0.05. Downstream from Huayuankou, Gaocun, Luokou, to Lijin, the average water discharge over the period from 1965 to 2014 decreased from 1060, 976, 852 to $782 \mathrm{~m}^{3} / \mathrm{s}$, and the average sediment discharge from 24.5, 20.1, 18.2 to $18.0 \mathrm{t} / \mathrm{s}$. The water discharge and sediment load of the lower Yellow River has decreased significantly because of both the reduction of rainfall in the Yellow River Basin since the 1970s [39,40] and the construction of reservoirs and the development of soil and water conservation projects [41]. Studies suggest that human activities contribute to more than $90 \%$ of the runoff decrease of the Yellow River [42]. As shown in Figure 3, the abrupt changes of water and sediment in the years from 1985-1996 given above occurred around the time of Longyangxia Reservoir being put into use (in 1986), yet the abrupt changes should be the results of the construction of all reservoirs and the application of water and soil conservation measures. 
(a)

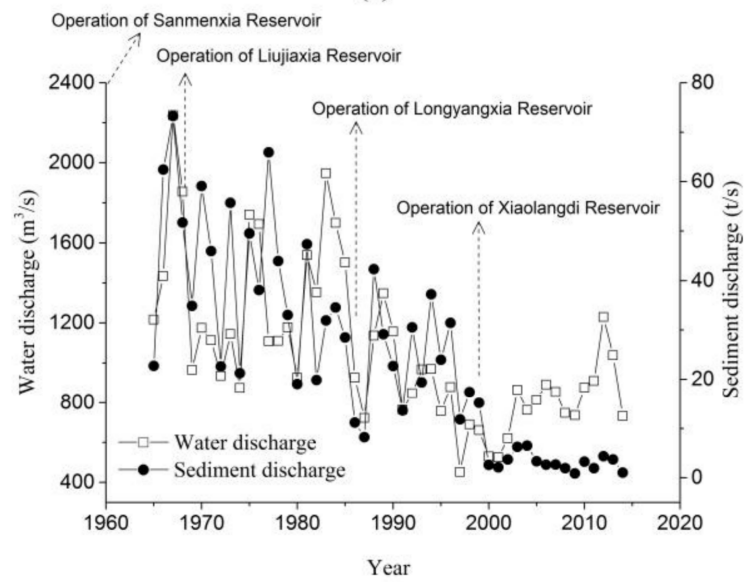

(c)

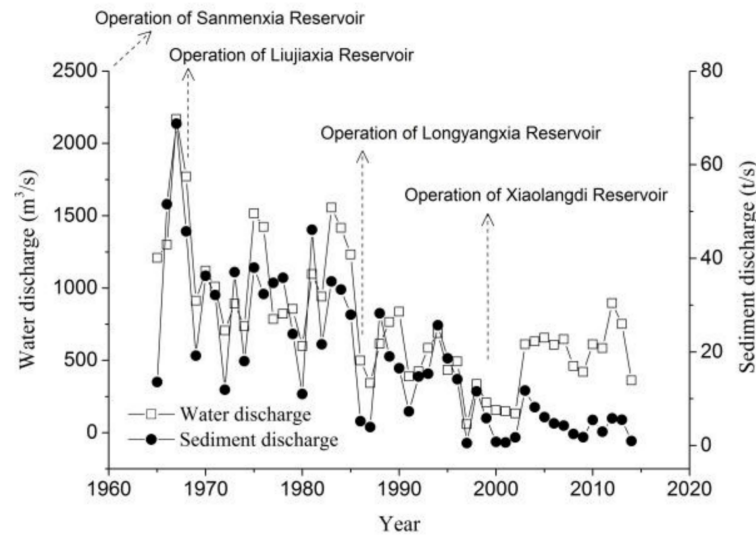

(b)

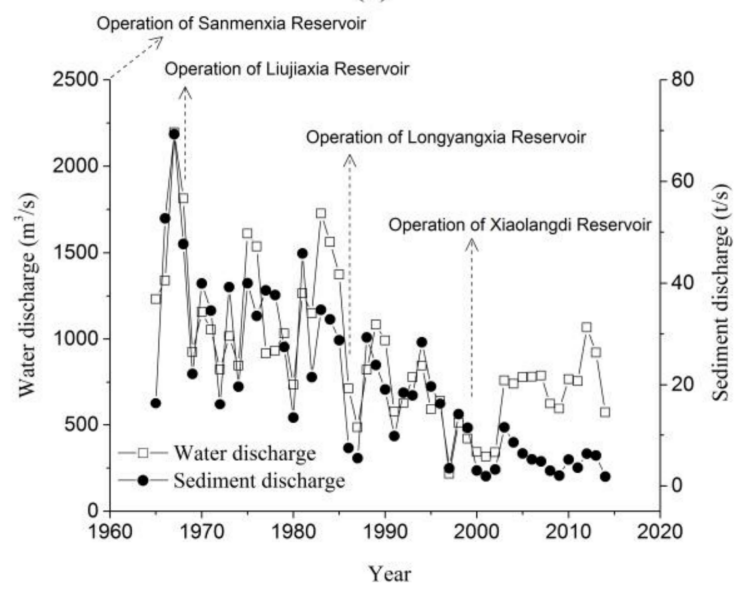

(d)

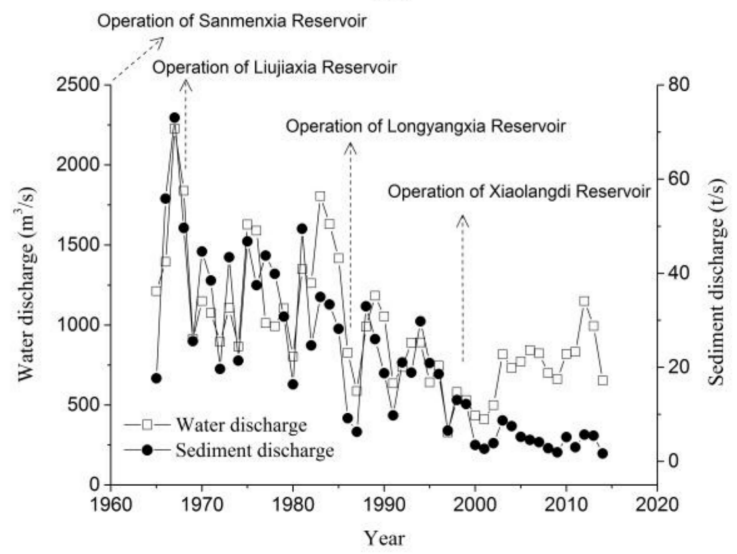

Figure 3. The annual mean water and sediment discharges at Huayuankou (a), Gaocun (b), Luokou (c) and Lijin (d) stations in the lower Yellow River.

\subsection{Changes in Channel Erosion/Deposition}

\subsubsection{Erosion/Deposition Variations of Whole Cross-Section}

As shown in Figure 4, the annual whole scouring and siltation amount of each of four cross-sections changed considerably. During the period under discussion, the Jiahetan section (Figure 4a) was silted for 13 years and eroded for 18 years. The scouring area exceeded $1000 \mathrm{~m}^{2}$ in 1981, 1982, 1986, 2008 and 2010, while the erosion/deposition area was less than $1000 \mathrm{~m}^{2}$ and kept at a nearly same level in other years except in 1977 when this section was greatly silted up in a hyperconcentrated flood, the recorded highest after 1969 [33]. In the Gaocun section (Figure 4b), siltation occurred in 16 years and erosion occurred in 16 years. The deposition area was greater than $1000 \mathrm{~m}^{2}$ in 1970, 1972, and 1976, and reached $1670 \mathrm{~m}^{2}$ in 1982. The Luokou section (Figure 4c) had a total of 18 years of siltation and 14 years of erosion. Except for the largest deposition area of $742 \mathrm{~m}^{2}$ in 1969, the deposition areas were all less than $450 \mathrm{~m}^{2}$ in the other years. The erosion area was in the range of 5-303 $\mathrm{m}^{2}$. Similarly to the Luokou section, the Lijin section (Figure $4 \mathrm{~d}$ ) also had 18 years of siltation and 14 years of erosion. The siltation in 1986 exceeded $1000 \mathrm{~m}^{2}$, while in all the other years it was less than $1000 \mathrm{~m}^{2}$. The erosion was less than $800 \mathrm{~m}^{2}$, and the maximum erosion occurred in 1985 .

Figure 5 shows the changes in cumulative erosion/deposition areas of channel cross-sections at four hydrological stations in the lower Yellow River. The cumulative erosion/deposition area of the Jiahetan section had a deposition trend before 1977 and an erosion trend after 1977, and the other three sections had an overall deposition trend. From 1966 to 2014 (except 1990 to 2008), the accumulated 
erosion/deposition areas at Jiahetan, Gaocun, Luokou and Lijin sections were $-375,4132,1120$, and $1165 \mathrm{~m}^{2}$, respectively.

(a)

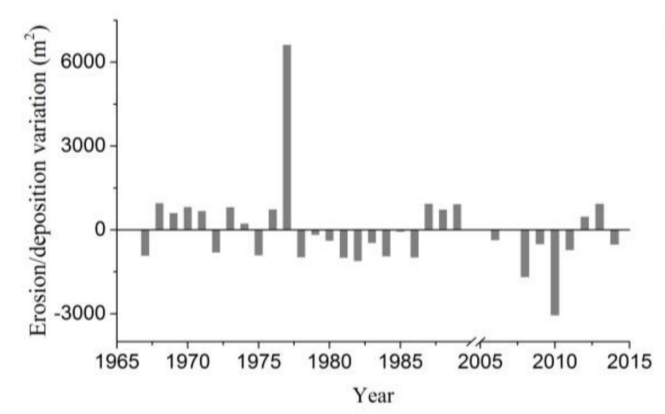

(c)

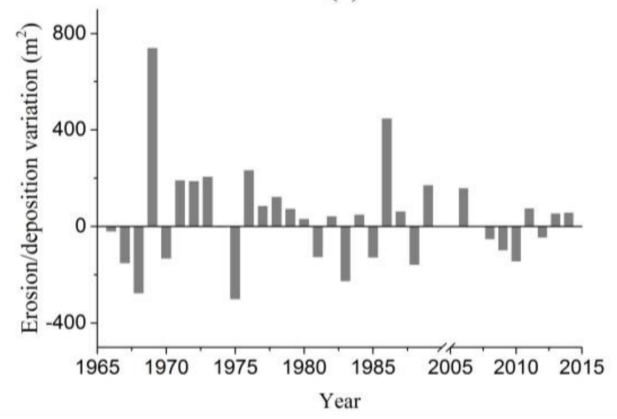

(b)

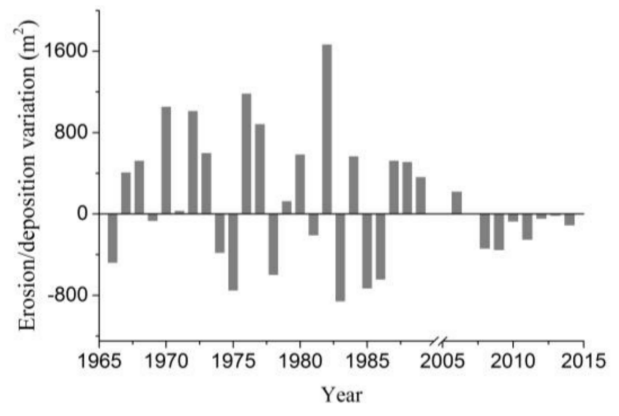

(d)

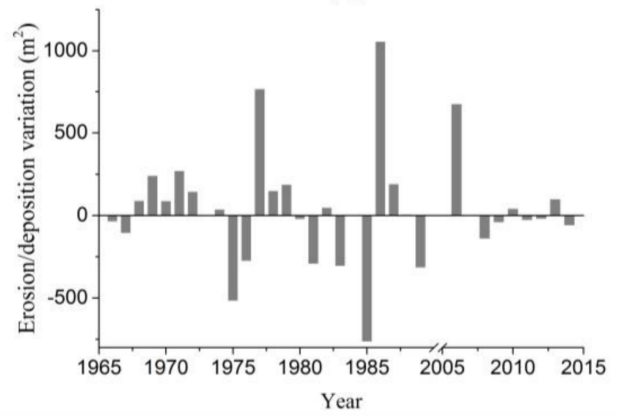

Figure 4. Changes of annual erosion/deposition in sections of Jiahetan (a), Gaocun (b), Luokou (c) and Lijin (d) in the lower Yellow River.

(a)

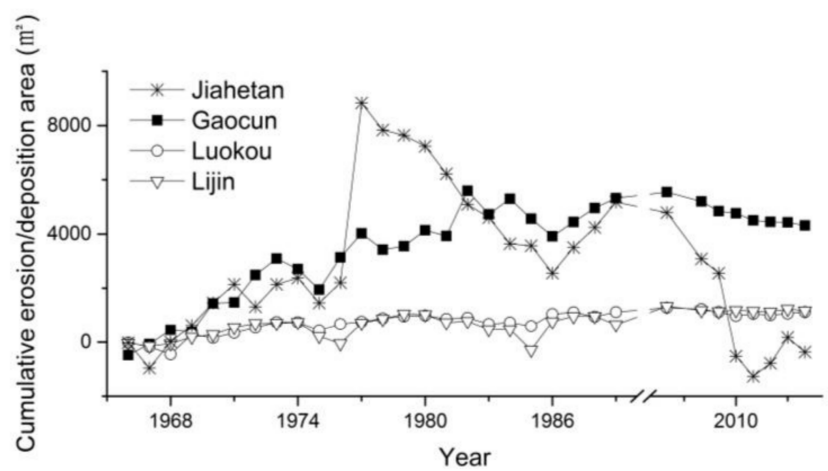

(b)

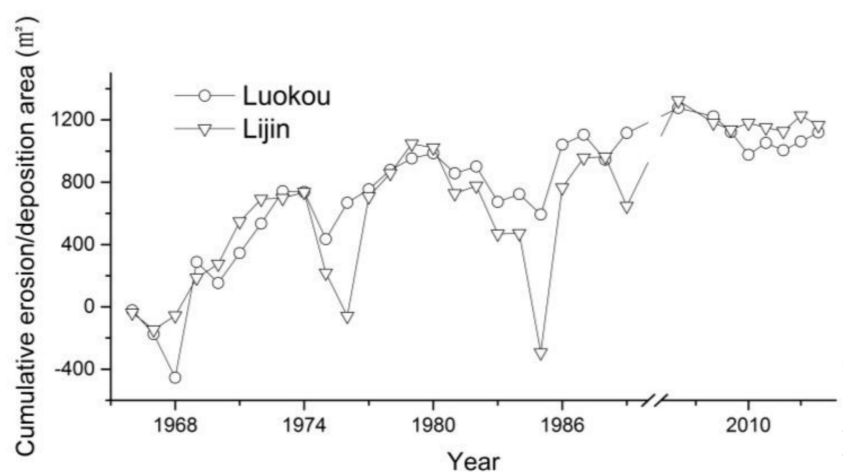

Figure 5. Accumulated erosion/accretion area of (a) Jiahetan, Gaocun, Luokou and Lijin; (b) Luokou and Lijinin sections the lower Yellow River. 


\subsubsection{Erosion/Deposition of Different Geomorphic Units in Channel Cross-Sections}

As shown in Figure 6a, the scouring and siltation of most geomorphic units in the Jiahetan section are relatively large, and those on the left and right low bank slopes, the main channel bed and the right low floodplain alternated more frequently.

(a)

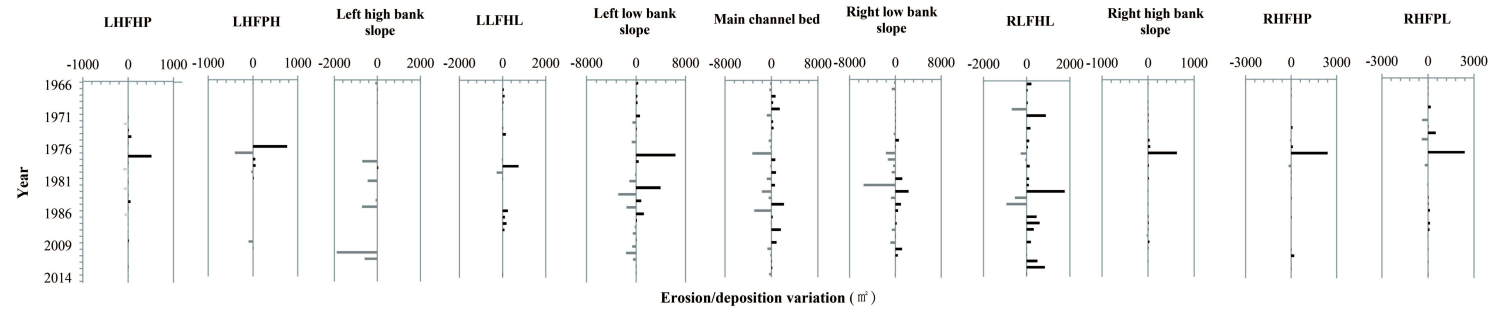

(b)

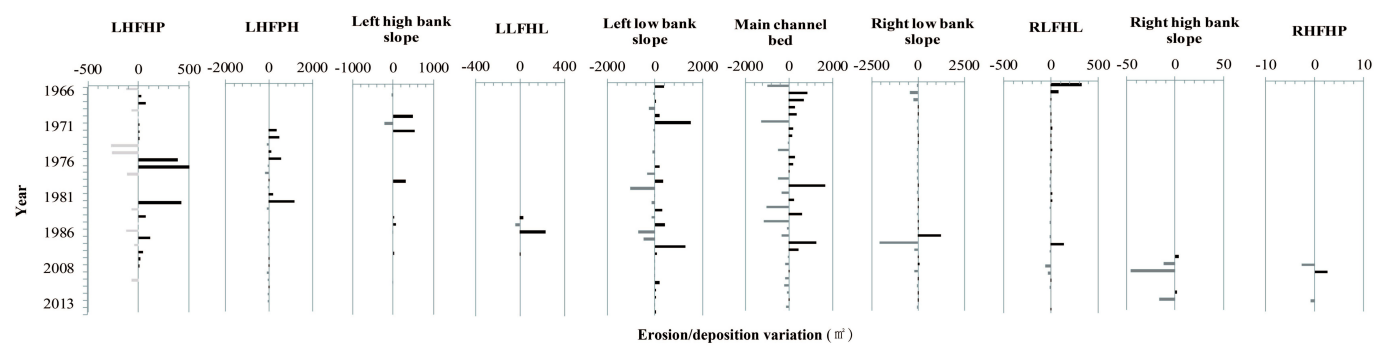

(c)

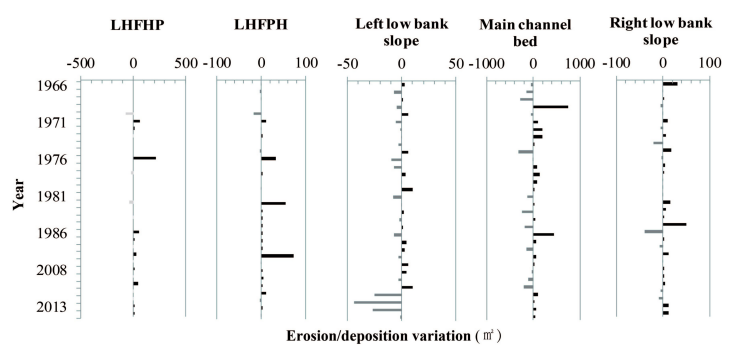

(d)

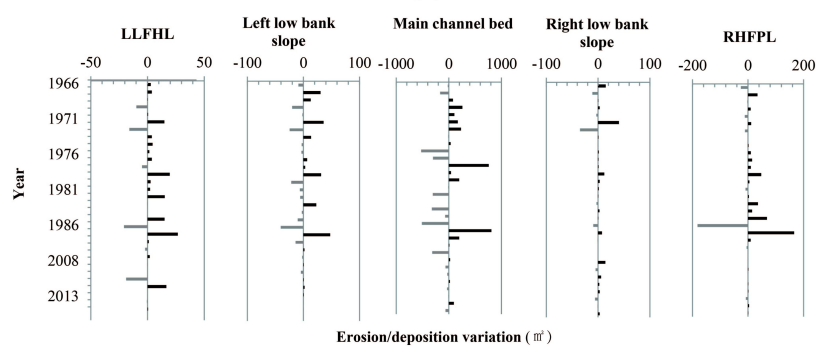

Figure 6. Changes in erosion and deposition of different geomorphic units in Jiahetan(a), Gaocun (b), Luokou (c) and Lijin (d) sections of the lower Yellow River.

In the Gaocun section in the transitional reach, the erosion and deposition are more severe on the main channel bed and the left low bank slope, followed by those on the left high floodplains both inside and outside of the production embankment and the left high bank slope. In 1982, the left high bank slope moved nearly $200 \mathrm{~m}$ to the left embankment, and sediments of $37.5 \mathrm{~cm}$ in thickness on average were accumulated on the left high floodplains, making the total sedimentation on the left floodplain a high peak. 
The Luokou section has the left high floodplains inside and outside the production embankment, the left low bank slope, main channel bed and right low bank slope. During the period under discussion, erosion and siltation mainly concentrated on the main channel bed and were much lower in the other geomorphic units. In 1976, the sediment deposition in the left high floodplain between the levee and production embankment was up to $216 \mathrm{~m}^{2}$, which was much higher than that in the other years.

The Lijin section only has the left low floodplain, left low bank slope, main channel bed, right low bank slope and right high floodplain between the levee and production embankment. Siltation and sedimentation mainly concentrated on the main channel bed. Only negligible erosion and deposition alternated frequently on the left low floodplain, left and right low bank slopes.

Generally, erosion and siltation mainly occurred on the main channel bed and the low bank slopes on both sides. The total erosion/deposition area of the left low bank slope of each of Jiahetan, Gaocun, Luokou and Lijin cross-sections accounted for $24.0 \%, 23.4 \%, 5.0 \%$, and $4.9 \%$, respectively, of the total erosion/deposition area of all geomorphic units of each section. The percentages were $25.7 \%, 37.7 \%, 74.6 \%$ and $78.3 \%$ for the main channel bed and were $23.0 \%, 13.6 \%, 4.8 \%$ and $5.3 \%$ for the right low bank slope. The percentage of scouring and silting area on the low bank slopes decreases downstream gradually, while that on the main channel bed increases downstream gradually. In other words, a downstream trend existed in the lower Yellow River from erosion/deposition on both the main channel bed and low bank slopes to erosion/deposition principally on the main channel bed.

\subsubsection{Erosion/Deposition of Low Bank Slopes and Channel Bed}

As siltation and erosion on the main channel bed and low bank slope have been more active than the other geomorphic units (Figure 6), we gave a further exploration to the processes of erosion and siltation in these two kinds of geomorphic units in both flood and non-flood or low flow seasons (Figure 7). Here, the erosion and siltation of the left and the right low bank slopes are summed.

(a)

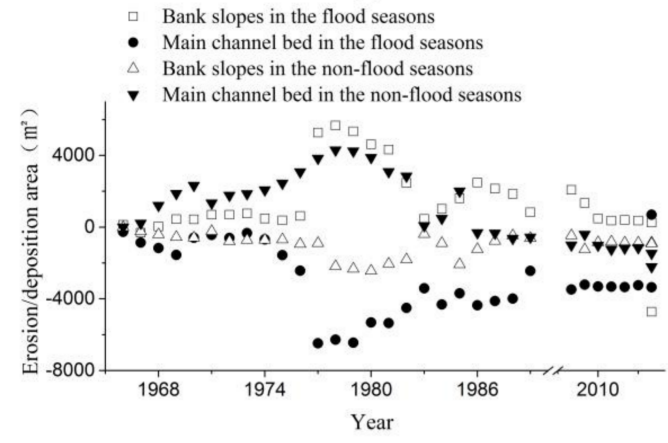

(c)

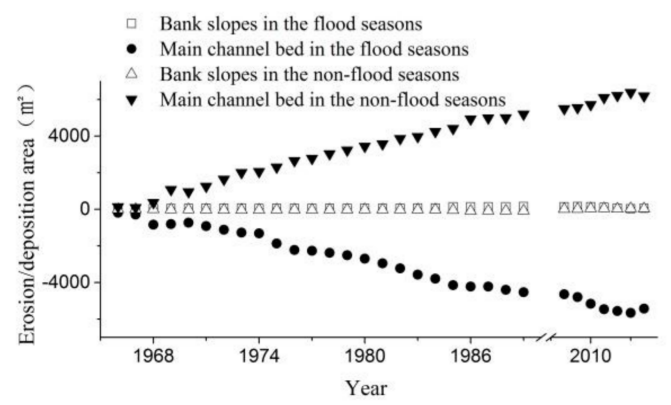

(b)

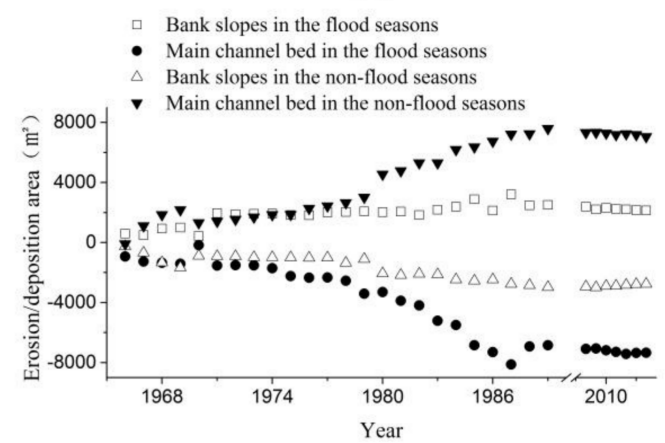

(d)

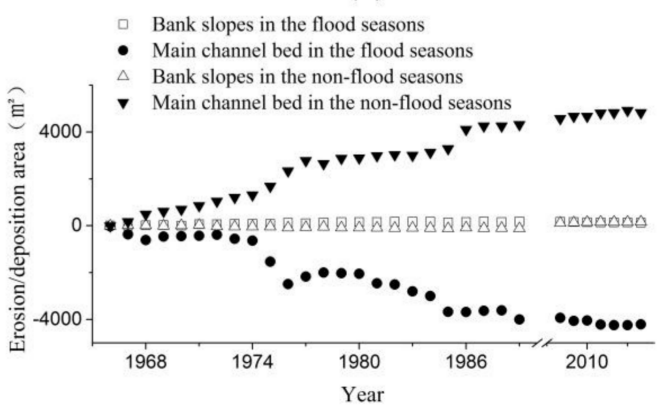

Figure 7. Cumulative seasonal erosion and siltation of bank slopes and main channel bed in Jiahetan (a), Gaocun (b), Luokou (c) and Lijin (d) sections of the lower Yellow River.

Figure 7a shows that the variations of erosion/deposition of the bank slopes and main channel bed of the Jiahetan section were relatively complex between 1966 and 1989. The bank slopes in flood 
seasons and the main channel bed in low flow seasons experienced roughly three cycles of transition from deposition to erosion, and the main channel bed in flood seasons and the bank slopes in non-flood seasons experienced same three cycles but started from erosion. After 2011, the bank slopes and the main channel bed in high and low flow seasons were basically in a state of equilibrium with negligible erosion and deposition. In Figure $7 \mathrm{~b}$, the siltation and erosion of the bank slopes and main channel bed of the Gaocun section were relatively regular. The bank slopes in flood seasons and the main channel bed in non-flood seasons were silted continuously from 1966 to 1969, eroded in 1970, gradually silted from 1971 to 1987, and slowly eroded after 2006. An erosion/deposition process opposite to that just stated occurred on the bank slopes in non-flood seasons and the main channel bed in flood seasons. The erosion/deposition processes of the main channel bed and bank slopes in Luokou (Figure 7c) and Lijin (Figure 7d) sections were basically the same. The main channel bed were gradually silted up in non-flood seasons and scoured in flood seasons gradually, while the bank slopes in non-flood and flood seasons were basically unchanged.

Figure 8 shows the cumulative erosion/deposition of the bank slopes and main channel bed of Jiahetan, Gaocun, Luokou and Lijin sections. It can be seen that the annual erosion/deposition area of main channel bed in the Jiahetan section changed slightly with a siltation trend before 1976 and had a large interannual variation with a continuous erosion trend after 1976 (Figure 8a). The annual cumulative erosion/deposition area of bank slopes changed little before 1976 but was raised suddenly by $4683.8 \mathrm{~m}^{2}$ in 1976 and followed by continuous scouring in 1977-1985. Bank slopes at this section were silted after 1985 and might be eroded after the construction of Xiaolangdi Dam, but erosion has been dampened considerably after 2010. The Gaocun section (Figure 8b) had a relatively large change in annual erosion/deposition of main channel bed and bank slopes before 1989, and its main channel bed was eroded unceasingly in a small annual amount and its bank slopes were nearly clear of erosion/deposition after 2006. In Luokou (Figure 8c) and Lijin sections (Figure 8d), the cumulative erosion/deposition area of bank slopes changed slightly excepts a rise between 1990 and 2006, while that of main channel bed changed obviously with an overall siltation trend but became comparatively stable after 2006.

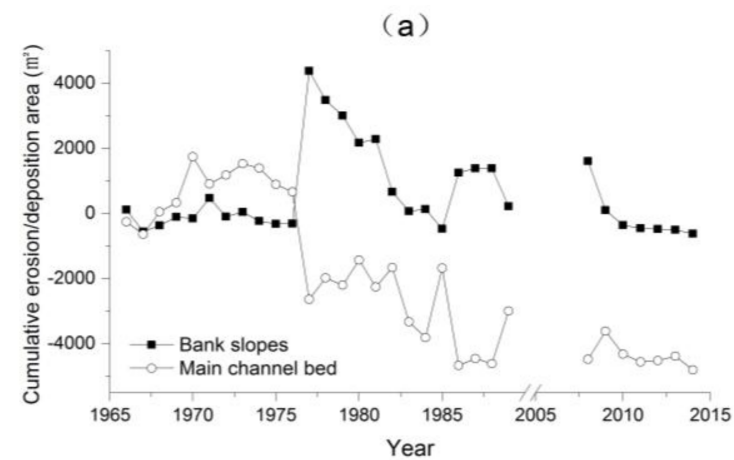

(c)

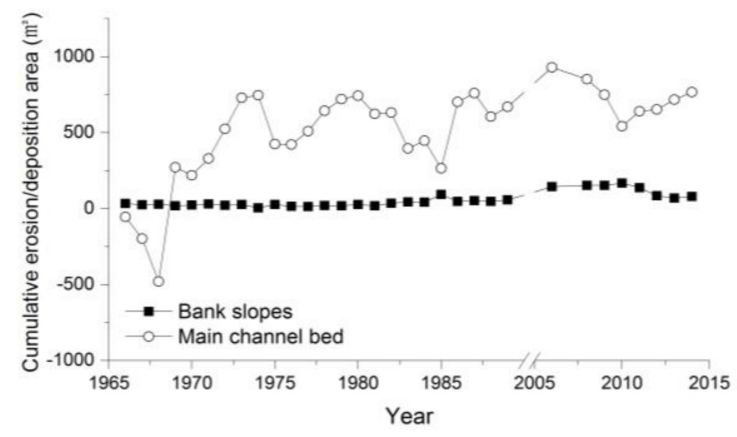

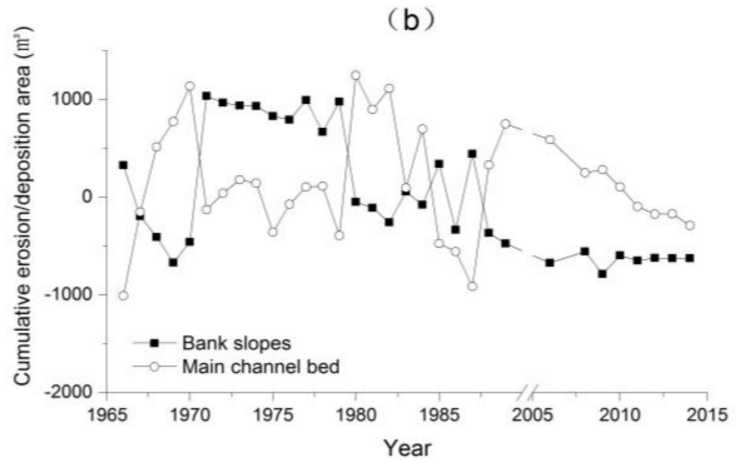

(d)

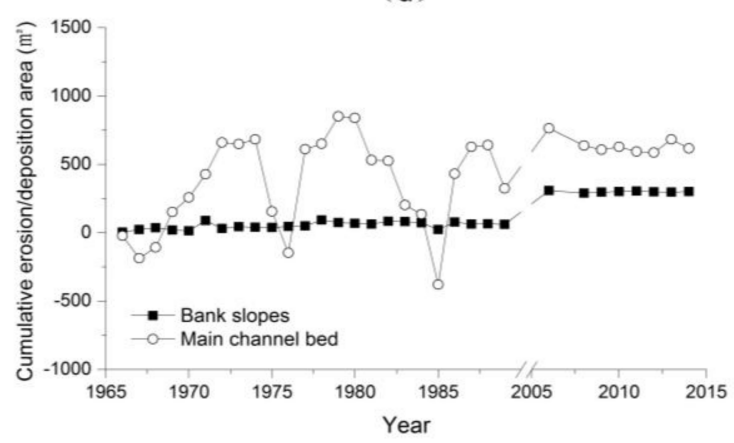

Figure 8. Cumulative erosion/deposition of bank slopes and main channel bed in Jiahetan (a), Gaocun (b), Luokou (c), and Lijin (d) sections of the lower Yellow River. 


\section{Discussion}

\subsection{Multi-year Channel Adjustment to Water and Sediment Changes}

Since the water and sediment discharge of four hydrological stations in the lower Yellow River all changed abruptly during the period from 1985 to 1996, the average water and sediment discharges before 1985 and after 1996 were calculated respectively. Before 1985, the average water discharge at Huayuankou, Gaocun, Luokou and Lijin was 1373.1, 1298.2, 1187.1, 1141.8 $\mathrm{m}^{3} / \mathrm{s}$, respectively. After 1996 , the average runoff was $776.7,698.1,589.8$ and $476.3 \mathrm{~m}^{3} / \mathrm{s}$, respectively. The water reduction rate was $43.4 \%, 46.2 \%, 46.5 \%$ and $58.3 \%$. Before 1985 , the average sediment concentration at Huayuankou, Gaocun, Luokou and Lijin was 30.4, 26.6, 26.3, $26.7 \mathrm{~kg} / \mathrm{m}^{3}$, respectively. After 1996, the average sediment concentration was $8.4,8.6,9.8,11.3 \mathrm{~kg} / \mathrm{m}^{3}$, and the reduction rate was $72.4 \%, 67.7 \%, 62.7 \%$, $57.7 \%$, respectively.

At a higher and more variable water discharge (Figure 3) and a higher sediment concentration before 1985, the channel scouring/silting changes greatly with an overall trend of siltation (Figures 4-6). The overall siltation trend did not occurred on the main channel bed and bank slopes at Jiahetan and Gaocun sections (Figure 8a,b) but on the floodplains (Figure 6a,b), and mainly on the main channel bed at Luokou and Lijin sections (Figure $6 c$,d and Figure 8c,d). In this period, the main channel bed and bank slopes were seasonally eroded and silted substantially and alternately (Figure 7). In contrast, after 2006, channel scouring in the Jiahetan section was considerable in the first four years, which occurred mainly on high and low bank slopes (Figures 5 and 6), and continuous channel erosion that concentrated on main channel bed could be noticed in the Gaocun section (Figures $5 \mathrm{a}$ and 8b), but erosion in the downstream two sections were comparatively weak (Figures $5 b$ and $8 c, d$ ). The main channel bed and bank slopes were eroded by a small amount both in the dry and wet seasons at Jiahetan and Gaocun sections after 2006 except for the minor siltation on bank slopes of Gaocun section in the dry seasons, while the seasonal erosion/deposition trends at Luokou and Lijin after 2006 were inherited from those before. The above contrasting channel adjustments between the two periods is consistent with the reduction of water and a sharper decline of sediment concentration after 1996. The same conclusion was given by Hu et al. [19], who reported the main channel bankfull capacity of the lower Yellow River was increasing with the increase of annual incoming water and the wandering section being more affected by the change of incoming water than the straight section.

Also, it can be found that channel adjustments at the four sections were different owing to, as mentioned above, the different changes of water discharge and sediment concentration downstream along the lower Yellow River after 2006. Figure 8a shows that the main channel bed and bank slopes of Jiahetan section in the wandering reaches had been in a graded state after 2010. The main channel bed at the Gaocun section in the transitional reaches has been scoured at a same rate up to now (Figure $8 b$ ). At Luokou and Lijin sections in the straight reaches, erosion/deposition on main channel bed and bank slopes was minor until now (Figure $8 \mathrm{c}, \mathrm{d}$ ). This should illustrate the downstream hysteretic response of channel adjustments to releasing water with a low sediment concentration from Xiaolangdi Reservoir, which retained sediments of $3.38 \times 10^{9} \mathrm{~m}^{3}$ in 1998-2017 [43], and to the marked reduction of runoff and sediment yield in the Yellow River basin.

\subsection{Causes for Seasonal Erosion and Deposition of Different Deomorphic Units}

The scouring and siltation of rivers are affected by the conditions of incoming water and sediment and boundary conditions of their channels. In the lower Yellow River, the channel boundary conditions have been changing constantly owing to active siltation and erosion. For a geomorphic unit of the river channel, the boundary conditions should include the scouring and silting of all the geomorphic units in the previous period and synchronous scouring and silting of the other geomorphic units. As existing boundary conditions, the impacts of scouring and silting in the previous period reflect their hysteresis effects. The influences of synchronous scouring and silting of other geomorphic units represent the effects of changing boundary conditions. For example, when studying the influencing 
factors of erosion/deposition on the main channel bed in a cross-section, it is necessary to consider not only the impacts of erosion/deposition on bank slopes and floodplains besides those of incoming water and sediment in the same period, but also the effects of erosion/deposition on the main channel bed, bank slopes and floodplains in the cross-section in the previous period.

In order to study the relationship of erosion and siltation of different geomorphic units with incoming runoff and sediment and various channel boundary conditions, a stepwise multiple regression analysis was performed on the scouring and siltation of geomorphic units in both flood and non-flood seasons, and the results are given in Table 1.

Table 1. Regression relations of erosion/deposition on different geomorphic units in four cross-sections in flood and non-flood seasons with influencing factors.

\begin{tabular}{|c|c|c|}
\hline Section & Flood Season & Non-flood Season \\
\hline Jiahetan & $\begin{array}{c}\mathrm{y}_{\mathrm{ba}}=-25.0-0.670 \mathrm{x}_{\mathrm{bo}}-0.582 \mathrm{x}_{\text {shoal }} \\
\left(\mathrm{r}^{2}=0.519, \mathrm{n}=29, \mathrm{p}<0.01\right) \\
\mathrm{y}_{\mathrm{bo}}=368.3-0.649 \mathrm{x}_{\mathrm{ba}}-0.276 \mathrm{x}_{\mathrm{q}} \\
\left(\mathrm{r}^{2}=0.507, \mathrm{n}=29, \mathrm{p}<0.01\right) \\
\mathrm{y}_{\text {shoal }}=193.4+0.388 \mathrm{x}_{\mathrm{ba}-1} \\
\left(\mathrm{r}^{2}=0.25, \mathrm{n}=29, \mathrm{p}<0.01\right)\end{array}$ & $\begin{array}{c}\mathrm{y}_{\mathrm{ba}}=0.945+0.329 \mathrm{x}_{\mathrm{bo}-1} \\
\left(\mathrm{r}^{2}=0.383, \mathrm{n}=30, \mathrm{p}<0.01\right) \\
\\
\mathrm{y}_{\text {shoal }}=456.1+0.907 \mathrm{x}_{\mathrm{hb}}-0.515 \mathrm{x}_{\mathrm{q}} \\
\left(\mathrm{r}^{2}=0.365, \mathrm{n}=30, \mathrm{p}<0.01\right)\end{array}$ \\
\hline Gaocun & $\begin{array}{c}\mathrm{y}_{\mathrm{ba}}=-48.8-0.535 \mathrm{x}_{\mathrm{bo}}-2.66 \mathrm{x}_{\text {shoal }-1} \\
\left(\mathrm{r}^{2}=0.610, \mathrm{n}=31, \mathrm{p}<0.01\right) \\
\mathrm{y}_{\mathrm{bo}}=-169.5-0.900 \mathrm{x}_{\mathrm{ba}} \\
\left(\mathrm{r}^{2}=0.497, \mathrm{n}=31, \mathrm{p}<0.01\right)\end{array}$ & $\begin{array}{c}\mathrm{y}_{\mathrm{ba}}=31.8-0.536 \mathrm{x}_{\mathrm{bo}} \\
\left(\mathrm{r}^{2}=0.649, \mathrm{n}=31, \mathrm{p}<0.01\right) \\
\mathrm{y}_{\mathrm{bo}}=-77.2-1.14 \mathrm{x}_{\mathrm{ba}}-0.213 \mathrm{x}_{\mathrm{bo}-1} \\
\left(\mathrm{r}^{2}=0.727, \mathrm{n}=31, \mathrm{p}<0.01\right) \\
\mathrm{y}_{\text {shoal }}=-9.14-0.056 \mathrm{x}_{\mathrm{bo}-1} \\
\left(\mathrm{r}^{2}=0.340, \mathrm{n}=31, \mathrm{p}<0.01\right)\end{array}$ \\
\hline Luokou & $\begin{array}{c}\mathrm{y}_{\mathrm{bo}}=60.2-0.118 \mathrm{x}_{\mathrm{q}}-0.313 \mathrm{x}_{\mathrm{bo}-1} \\
\left(\mathrm{r}^{2}=0.364, \mathrm{n}=31, \mathrm{p}<0.01\right) \\
\mathrm{y}_{\mathrm{h}}=3.16+0.307 \mathrm{x}_{\mathrm{h}-1} \\
\left(\mathrm{r}^{2}=0.18, \mathrm{n}=31, \mathrm{p}<0.05\right)\end{array}$ & $\begin{array}{c}\mathrm{y}_{\mathrm{ba}}=2.15-0.284 \mathrm{x}_{\mathrm{h}} \\
\left(\mathrm{r}^{2}=0.346, \mathrm{n}=31, \mathrm{p}<0.01\right) \\
\mathrm{y}_{\mathrm{bo}}=78.5-0.657 \mathrm{x}_{\mathrm{bo}-1} \\
\left(\mathrm{r}^{2}=0.324, \mathrm{n}=31, \mathrm{p}<0.01\right) \\
\mathrm{y}_{\mathrm{h}}=5.3-1.22 \mathrm{x}_{\mathrm{ba}} \\
\left(\mathrm{r}^{2}=0.346, \mathrm{n}=31, \mathrm{p}<0.01\right)\end{array}$ \\
\hline Lijin & $\begin{array}{c}\mathrm{y}_{\mathrm{ba}}=6.743+1.949 \mathrm{x}_{\text {shoal }} \\
\left(\mathrm{r}^{2}=0.346, \mathrm{n}=31, \mathrm{p}<0.01\right) \\
\mathrm{y}_{\mathrm{bo}}=170.344-0.214 \mathrm{x}_{\mathrm{q}} \\
\left(\mathrm{r}^{2}=0.372, \mathrm{n}=31, \mathrm{p}<0.01\right) \\
\mathrm{y}_{\text {shoal }}=1.20+0.147 \mathrm{x}_{\mathrm{h}}+0.076 \mathrm{x}_{\mathrm{ba}} \\
\left(\mathrm{r}^{2}=0.682, \mathrm{n}=31, \mathrm{p}<0.01\right) \\
\mathrm{y}_{\mathrm{h}}=2.02+3.63 \mathrm{x}_{\text {shoal }} \\
\left(\mathrm{r}^{2}=0.634, \mathrm{n}=31, \mathrm{p}<0.01\right)\end{array}$ & $\begin{array}{c}\mathrm{y}_{\mathrm{bo}}=-14.117-0.389 \mathrm{x}_{\text {bo- }-1}-2.321 \mathrm{x}_{\mathrm{h}-1}+0.186 \mathrm{x}_{\mathrm{q}} \\
\left(\mathrm{r}^{2}=0.684, \mathrm{n}=31, \mathrm{p}<0.01\right) \\
\mathrm{y}_{\text {shoal }}=2.07-0.895 \mathrm{x}_{\text {shoal }-1} \\
\left(\mathrm{r}^{2}=0.340, \mathrm{n}=31, \mathrm{p}<0.01\right)\end{array}$ \\
\hline
\end{tabular}

The subscripts in the table, " $\mathrm{s}$ " denotes the mean sediment discharge $(\mathrm{t} / \mathrm{s})$, " $\mathrm{q}$ " denotes the mean water discharge $\left(\mathrm{m}^{3} / \mathrm{s}\right)$, "ba" denotes the bank slopes, "bo" denotes the main channel bed, "shoal" denotes the low floodplains, " $\mathrm{hb}$ " denotes the high floodplain bank slopes, " $\mathrm{h}$ " expresses the high floodplains, and "- 1 " indicates the previous season. Erosion/deposition has a unit of $\mathrm{m}^{2}$.

The regression relations for the Jiahetan section show that the erosion/deposition of geomorphic units in flood seasons influence on each other significantly, while the impacts of changes in water and sediment discharges are mostly insignificant. The same characteristics exist in the Gaocun section. In the Luokou section, the erosion/deposition of main channel bed in flood seasons has a negative relation with that of the same unit in the previous non-flood seasons and the mean water discharge in flood seasons. In the Lijin section, the erosion/deposition of bank slopes in flood seasons is positively related with the erosion/deposition of low floodplains in flood seasons, and the erosion/deposition of main channel bed is negatively related with the mean water discharge. The low water and sediment discharges in non-flood seasons had an insignificant impact on the changes in erosion/siltation of all geomorphic units in most cases in all the four sections.

The erosion/deposition on main channel bed has a direct impact on the perching state of the river channel, so here it is given a further analysis. Table 1 shows that in the Jiahetan section in the wandering reaches and the Gaocun section in the transitional reaches, the erosion/deposition of 
main channel bed during the flood and non-flood seasons are mainly affected by that of bank slopes. Specifically, erosion on the bank slopes will promote siltation on the main channel bed in these two sections. The regression relation between erosion/deposition on main channel bed and influencing factors for the Jiahetan section disclose that $1 \mathrm{~m}^{2}$ of erosion on bank slopes results in $0.649 \mathrm{~m}^{2}$ of siltation on main channel bed in flood seasons. In the Gaocun section, $1 \mathrm{~m}^{2}$ of erosion on the bank slopes results in $0.9 \mathrm{~m}^{2}$ of siltation on main channel bed in flood seasons and $1.14 \mathrm{~m}^{2}$ of siltation on main channel bed in low flow seasons. In contrast, in Luokou and Lijin sections in the straight reaches, the erosion and deposition in flood seasons are greatly influenced by the water discharge, with an increase of mean water discharge by $1 \mathrm{~m}^{3} / \mathrm{s}$ inducing $0.118 \mathrm{~m}^{2}$ of erosion on the channel bed in the Luokou section and $0.214 \mathrm{~m}^{2}$ of erosion on the channel bed in Lijin section. Although siltation on channel bed of the two sections in low flow seasons is encouraged by erosion on channel bed in the previous flood seasons, the ratios are below one, i.e., 0.657 in Luokou section and 0.389 in Lijin section. Incessant siltation on the main channel bed has been the principal cause for the formation of the two-level perching channel of the river. Thus, for the purpose of alleviating the uplift of the perching channel and even further lowering the channel, it is better to fix the river banks in the wandering and transitional reaches, and to raise the water discharge in the flood seasons.

\section{Conclusions}

The runoff and sediment load of the lower Yellow River have changed considerably in the past decades. Both the annual mean water and sediment discharges at hydrological stations along the river have a significant downward trend with an abrupt change occurred in the period of 1985-1996. With the marked changes in water and sediment discharges, the lower Yellow River channel adjusts in a complex manner. In the period before the abrupt change, the river had a large and highly variable water discharge as well as a high sediment load, and the river channel was silted or eroded with an overall siltation trend. In the wandering and transitional reaches, siltation mainly occurred on floodplains, and erosion/deposition in the main channel was much active but long-term cumulative siltation was insignificant. The main channel bed at the Jiahetan section in the wandering reaches was even eroded over the period. In the straight reaches, siltation occurred principally on main channel bed while bank slopes were scarcely silted or eroded. In the period after the abrupt change, with much lower water and sediment discharges, erosion dominated the lower Yellow River channel but was comparatively minor in the straight reaches. The erosion had been dampened in the wandering reaches after 2010, remained at a constant rate in the transitional reaches, and might be enhanced in the straight reaches in the future.

The seasonal erosion and deposition of various geomorphic units are related to one or more of the previous and concurrent erosion and deposition of some other geomorphic units, the previous erosion and deposition of themselves, as well as the changes in incoming water and sediment. It was found that erosion on bank slopes could cause siltation on main channel bed in both the Jiahetan section in the wandering reaches and the Gaocun section in the transitional reaches, and siltation on main channel bed in flood seasons has been negatively related with the mean water discharge in both Luokou and Lijin sections in the straight reaches. Thus, stabilizing the bank slopes in the wandering and transitional reaches and increasing the water discharge in flood seasons should be favorable for restraining the development of the two-level perching channel of the lower Yellow River.

Author Contributions: X.L. took the lead in writing the manuscript; C.S. revised the manuscript and supervised the research work; Y.Z., Z.G. and H.L. offered guidance and suggestions to the manuscript.

Funding: This study was funded by National Key Research and Development Program of China (No. 2016YFC0402502, 2017YFC0405506) and the National Natural Science Foundation of China (No. 41501009).

Conflicts of Interest: The authors declare no conflict of interest. 


\section{References}

1. Milliman, J.D.; Meade, R.H. World-wide delivery of river sediment to the oceans. J. Geol. 1983, 91, 1-21. [CrossRef]

2. Petts, G.E. Impounded Rivers: Perspectives for Ecological Management; John Wiley: New York, NY, USA, 1984; p. 344.

3. Lu, X.; Higgitt, D.L. Recent changes of sediment yield in the Upper Yangtze, China. Environ. Manag. 1998, 22, 697-709. [CrossRef]

4. Kesel, R.H. Human modifications to the sediment regime of the Lower Mississippi River flood plain. Geomorphology 2003, 56, 325-334. [CrossRef]

5. Phillips, J.D.; Slattery, M.C.; Musselman, Z.A. Dam-to-delta sediment inputs and storage in the lower trinity river, Texas. Geomorphology 2004, 62, 17-34. [CrossRef]

6. Syvitski, J.P.; Vörösmarty, C.J.; Kettner, A.J.; Green, P. Impact of humans on the flux of terrestrial sediment to the global coastal ocean. Science 2005, 308, 376-380. [CrossRef] [PubMed]

7. Dai, S.B.; Lu, X.X.; Yang, S.L.; Cai, A.M. A preliminary estimate of human and natural contributions to the decline in sediment flux from the Yangtze River to the East China Sea. Quat. Int. 2008, 186, 43-54. [CrossRef]

8. Dabney, S.; Yoder, D.; Vieira, D. The application of the Revised Universal Soil Loss Equation, Version 2 , to evaluate the impacts of alternative climate change scenarios on runoff and sediment yield. J. Soil Water Conserv. 2012, 67, 343-353. [CrossRef]

9. Vörösmarty, C.J.; Meybeck, M.; Fekete, B.; Sharma, K.; Green, P.; Syvitsk, J.P.M. Anthropogenic sediment retention: Major global impact from registered river impoundments. Glob. Planet. Chang. 2003, 39, 169-190. [CrossRef]

10. Bruschi, V.M.; Bonachea, J.; Remondo, J.; Gómez-Arozamena, J.; Rivas, V.; Méndez, G.; Naredo, J.M.; Cendrero, A. Analysis of geomorphic systems' response to natural and human drivers in northern Spain: Implications for global geomorphic change. Geomorphology 2013, 196, 267-279. [CrossRef]

11. Yu, Y.G.; Wang, H.J.; Shi, X.F.; Ran, X.B.; Cui, T.W.; Qiao, S.Q.; Liu, Y.G. New discharge regime of the Huanghe (Yellow River): Causes and implications. Cont. Shelf Res. 2013, 69, 62-72. [CrossRef]

12. Graf, W.L. Dam nation: A geographic census of American dams and their large-scale hydrologic impacts. Water Resour. Res. 1999, 35, 1305-1311. [CrossRef]

13. Yang, S.L.; Milliman, J.D.; Xu, K.H.; Deng, B.; Zhang, X.Y.; Luo, X.X. Downstream sedimentary and geomorphic impacts of the three gorges dam on the Yangtze River. Earth-Sci. Rev. 2014, 138, 469-486. [CrossRef]

14. Williams, G.P.; Wolman, M.G. Downstream Effects of Dams on Alluvial Rivers. Professional Paper 1286; US Geological Survey: Washington, DC, USA, 1984; p. 83.

15. Xu, J.X.; Shi, C.X. River bank erosion downstream from the Danjiangkou reservoir and its implications in river channel adjustment. Chin. Sci. Bull. 1995, 40, 1689-1692.

16. Shen, G.Q.; Zhang, Y.F.; Hou, S.Z.; Shang, H.X. Impact of water and sediment regulation by reservoirs in the upper Yellow River on Inner-Mongolia reaches. J. Sediment Res. 2007, 1, 67-75, (In Chinese with English abstract).

17. Chu, Z.X. The dramatic changes and anthropogenic causes of erosion and deposition in the lower Yellow (Huanghe) River since 1952. Geomorphology 2014, 216, 171-179. [CrossRef]

18. Yao, W.Y.; Peng, N.Z.; Yang, D.F. Some theoretical foundations for influences of soil and water conservation on river system. J. Sediment Res. 1999, 4, 22-27, (In Chinese with English abstract).

19. Hu, Y.S.; Zhang, X.H. Brief discussion on the secondary perched river. J. Sediment Res. 2006, 5, 1-9, (In Chinese with English abstract).

20. $\mathrm{Xu}, \mathrm{J} . \mathrm{X}$. Trend of sediment yield in the coarser sediment-producing area in the middle Yellow River basin in the period 1997-2007 and the formative cause. J. Soil Water Conserv. 2010, 24, 1-7, (In Chinese with English abstract).

21. Wu, B.S.; Xia, J.Q.; Fu, X.D.; Zhang, Y.F.; Wang, G.Q. Effect of altered flow regime on bankfull area of the Lower Yellow River, China. Earth Surf. Process. Landf. 2008, 33, 1585-1601. [CrossRef]

22. Mu, X.M.; Wang, W.Z.; Gao, P.; Zhao, G.J. Progress and discussion on sediment load variation research of the Yellow River. Yellow River 2014, 36, 1-7, (In Chinese with English abstract). 
23. Xia, J.Q.; Li, J.; Zhang, S.Y. Channel adjustments in the lower Yellow River after the operation of Xiaolangdi Reservoir. Yellow River 2016, 38, 49-55, (In Chinese with English abstract).

24. Brice, J.C. Stream channel stability assessment. In Report No. FHWA-RD-82-021, Federal Highway Administration; US Department of Transportation: Washington, DC, USA, 1982; p. 42.

25. Friedman, J.M.; Osterkamp, W.R.; Scott, M.L.; Auble, G.T. Downstream effects of dams on channel geometry and bottomland vegetation: Regional patterns in the Great Plains. Wetlands 1998, 18, 619-633. [CrossRef]

26. Hupp, C.R.; Demas, C.R.; Kroes, D.E.; Day, R.H.; Doyle, T.W. Recent sedimentation patterns within the central Atchafalaya Basin, Louisiana. Wetlands 2008, 8, 125-140. [CrossRef]

27. Petts, G.E. Complex response of river channel morphology to reservoir construction. Prog. Phys. Geogr. 1979, 3, 329-362. [CrossRef]

28. Hoffmann, T.; Thorndycraft, V.R.; Brown, A.G.; Coulthard, T.J.; Damnati, B.; Kale, V.S.; Middelkoop, H.; Notebaert, B.; Walling, D.E. Human impact on fluvial regimes and sediment flux during the Holocene: Review and future research agenda. Glob. Planet. Chang. 2010, 72, 87-98. [CrossRef]

29. Heitmuller, F.T. Channel adjustments to historical disturbances along the lower Brazos and Sabine Rivers, south-central USA. Geomorphology 2014, 204, 382-398. [CrossRef]

30. Zhang, D.; Shi, C.X. Sedimentary causes and management of two principal environmental problems in the lower Yellow River. Environ. Manag. 2001, 28, 749-760.

31. Zhao, Y.A.; Pan, X.D.; Li, Y. Variation of water and sediment of the Yellow River and development trend of the lower Yellow River course. Yellow River 1994, 2, 31-34, 41, 62, (In Chinese with English abstract).

32. Pan, X.D.; Li, Y.; Zhang, X.H. River Bed Evolution in the Lower Yellow River after the Construction of Sanmenxia Reservoir; Yellow River Conservancy Press: Zhengzhou, China, 2006; pp. 110-112. (In Chinese)

33. Shen, G.Q.; Zhang, Y.F.; Zhang, M. Definition of channel and floodplain and spatio-temporal sedimentation characteristics for overbank hyperconcentrated flood in the lower Yellow River. Adv. Water Sci. 2017, 28, 641-651, (In Chinese with English abstract).

34. Zhao, Y.A.; Pan, X.D.; Liu, Y.L.; Han, S.F.; Fan, Z.Y. Siltation of the lower Yellow River and estimation of recent development trends. In Yellow River Research and Practice; Water Conservancy and Electric Power Press: Beijing, China, 1986; pp. 58-69. (In Chinese)

35. Chen, J.G.; Zhou, W.H.; Chen, Q. Channel re-establishment of the Lower Yellow River in ten years operation of Xiaolangdi Reservoir. J. Hydraul. Eng. 2012, 43, 127-135, (In Chinese with English abstract).

36. Guo, S.L. The Flood Control Technology of the Lower Yellow River Based on Deposition on the Floodplain and Scour in the Main Channel. Ph.D. Thesis, Beijing Forestry University, Beijing, China, 2013. (In Chinese with English abstract).

37. Yu, Y.S.; Chen, X.W. Study on the percentage of trend component in a hydrological time series based on Mann-Kendall method. J. Nat. Resour. 2011, 26, 1585-1591, (In Chinese with English abstract).

38. Pettitt, A.N. A non-parametric approach to the change-point problem. Appl. Stat. 1979, 28, 126-135. [CrossRef]

39. Zhang, G.S.; Li, L.; Shi, X.H.; Dong, L.X.; Wang, Q.C. Climatic changes over the Upper Yellow River and its effects on water resources. Adv. Water Sci. 2000, 11, 277-283, (In Chinese with English abstract).

40. Zhang, J.Y.; Wang, G.Q.; He, R.M.; Liu, C.S. Variation trends of runoffs in the Middle Yellow River basin and its response to climate change. Adv. Water Sci. 2009, 20, 153-158, (In Chinese with English abstract).

41. $\mathrm{Xu}, \mathrm{J} . \mathrm{X}$. The water fluxes of the yellow river to the sea in the past 50 years, in response to climate change and human activities. Environ. Manag. 2005, 35, 620-631.

42. Kong, D.; Miao, C.; Wu, J.; Duan, Q. Impact assessment of climate change and human activities on net runoff in the Yellow River basin from 1951 to 2012. Ecol. Eng. 2016, 91, 566-573. [CrossRef]

43. Yellow River Conservancy Commission (YRCC) of Ministry of Water Resources, China. Yellow River Sediment Bulletin in 2017. Available online: http://www.yellowriver.gov.cn/nishagonggao/2017/ (accessed on 18 February 2019).

(C) 2019 by the authors. Licensee MDPI, Basel, Switzerland. This article is an open access article distributed under the terms and conditions of the Creative Commons Attribution (CC BY) license (http:/ / creativecommons.org/licenses/by/4.0/). 